\title{
Anchoring Effects: Evidence from Art Auctions
}

\author{
By Alan Beggs and Kathryn Graddy*
}

Suppose two Matisse paintings with identical characteristics were put up for sale. However, one of the paintings had previously been sold in a "hot" market for a high price and the other had been sold in a "cold" market for a low price. Would the painting that previously sold in the "hot" market fetch a higher price at auction?

Anchoring is one of the most powerful and well-established biases in laboratory experiments. A classic example is given in Amos Tversky and Daniel Kahneman (1982) when subjects are asked to estimate a number (for example the percentage of African countries in the United Nations). The experiment begins by the subjects being given a number between 1 and 100 that is determined by a spin of a wheel. The subjects then show a bias in their final estimates toward the number they were originally given. Such overweighting of often irrelevant initial cues in judgement has been documented in a wide range of laboratory experiments. ${ }^{1}$ Yet very little work has been done to establish the presence of the anchoring heuristic in real economic situations. ${ }^{2}$ We test for anchoring effects both on actual prices in art auctions, and on experts' presale valuations.

In order to separate anchoring (where an irrelevant message has an effect on the outcome) from rational learning (where past prices are not irrelevant because they may be used to estimate unobservable quality) we use the following strategy. We first develop a hedonic prediction of price for both the current sale (e.g., the 2006 sale) and the previous sale. These hedonic predictions are based on observable characteristics of each painting and an index of overall prices. We then regress actual sale price on our hedonic prediction, on the difference between the actual price in the previous sale and our hedonic prediction (this expression tests for anchoring), and on the difference between the actual price in the previous sale and our hedonic prediction of price in the previous sale (this expression controls for unobservable characteristics). The test for anchoring is the extent to which the actual price in the previous sale affects the current sale price. We can identify anchoring from other effects because the demand for art, which is captured by the average overall price index, changes over time, whereas the unobservable component of quality is assumed to remain constant between auctions. This allows us to control for unobserved quality characteristics. As long as something drastic has not happened between sales-such as a painting has been deemed a fake, which is a very rare occurrence-the assumption of constant quality is a realistic one.

* Beggs: Department of Economics, Oxford University, Manor Road Building, Manor Road, Oxford OX1 3UQ, United Kingdom (e-mail: alan.beggs@economics.ox.ac.uk); Graddy: Department of Economics and International Business School, Brandeis University, MS 021, 415 South Street, Waltham, MA 02453 (e-mail: kgraddy@brandeis. edu). The authors would like to thank seminar participants at the University of Edinburgh, Universidade Catolica Portuguese at Porto, and the University of Warwick for very useful comments. The authors are especially grateful to two anonymous referees.

${ }^{1}$ See, for example, Gretchen B. Chapman and Eric J. Johnson (2002) for a survey and discussion.

${ }^{2}$ Gregory B. Northcraft and Margaret A. Neale (1987) investigate the effect of manipulating the alleged list price on valuations of properties by estate agents. This, however, is still not in a true market context. K. N. (Raj) Rajendran and Gerard J. Tellis (1994) and Eric A. Greenleaf (1995) examine the importance of past prices when consumers repeatedly purchase the same commodity. Since the good is purchased several times it seems unlikely that consumers are using past prices to estimate the "quality" of the good. Loss aversion has been studied more widely: see, for example, David Genesove and Christopher J. Mayer (2001) on the housing market and Nicholas Barberis, Ming Huang, and Tano Santos (2001) on the stock market. 
This paper finds that the current price is influenced by the previous price. In an auction environment, this implies that bidders are anchoring their bids (either on the previous price or the presale estimate). The evidence does not, however, confirm whether sellers and auctioneers are also anchoring or are simply responding to anchoring on the part of the bidders.

The paper proceeds as follows. In Section I we describe art auctions and in Section II we describe possible anchoring effects in art auctions. In Section III we construct our empirical model and describe the intuition behind the empirical model. In Section IV we present our regression estimates, and in Section V we interpret and conclude our analysis.

\section{How Art Auctions Work}

If a person wishes to sell a piece of art, he has the choice of taking it to a dealer or to an auction house. The major auction houses are the English houses of Christie's and Sotheby's. An art expert at the auction house will provide advice on the likely valuation of the painting, and together the seller and the expert will come up with a secret reserve price.

Prior to an auction, a presale catalogue is published with information on the individual items coming up for sale. Included in the presale catalogue is information on the title of a painting, the artist, the size of the painting, and the medium. The auction houses also publish a low- and a high-price estimate for the work. The auction house does not publish, and indeed is very secretive about, the seller's reserve price for the work of art. The auction houses observe an unwritten rule that the published low estimate is set at or above the secret reserve price.

Almost all art is auctioned in the "English" or "ascending price" format. Bidding starts low, and the auctioneer subsequently calls out higher and higher prices. When the bidding stops, the item is said to be "knocked down" or "hammered down," and the final price is the "hammer price." Not all items that have been put up for sale and "knocked down" have been sold. If the bidding does not reach the level of the secret reserve price, the item will go unsold. Auctioneers say that an unsold item has been "bought-in." It may be put up for sale at a later auction, sold elsewhere, or taken off the market.

The important participants in art auctions are the buyers, the sellers, and the auctioneers. The auctioneers employ professionals who use their "expert knowledge" of art and the current state of the market to develop presale estimates. The buyers and sellers are primarily a mixture of professional art dealers and private collectors. All three of these participants generally know the price at which a painting previously sold at auction. The auctioneer is usually happy to provide this information to buyers who are interested in a painting and to sellers of a painting. Buyers and sellers can also find this information themselves currently through a number of online providers of art auction prices, and historically through print versions of art sales prices such as the Art Sales Index.

\section{Anchoring in Art Auctions}

\section{A. Buyers}

In the absence of sellers' reserve prices in art auctions, all items would be sold (no sample selection issues), ${ }^{3}$ and the price would be the valuation of the second highest bidder. Observed

\footnotetext{
${ }^{3}$ Sellers may of course delay, if they are able, bringing items to the market if prospects are poor. William M. Taylor (1983) argues that much of the variation in measured returns to stamps between auction is due to variations in the quality of stamps brought to auction. This is less of a concern in our data, as we use repeat observations on the same paintings.
} 
effects would be entirely attributable to the buyer, anchoring on either the previous sale price or the presale estimate. Anchoring might be relevant to a buyer in determining his reservation price because paintings are unique items. In the psychology literature, it is generally perceived that anchoring effects are stronger in the absence of other clues. Hence, even after controlling for all painting characteristics, the nominal value of the previous sale price can influence a buyer's valuation.

\section{B. Sellers}

In the presence of sellers' reserve prices, anchoring effects can also be attributed to the seller. If there is only one bidder who is willing to meet the seller's reserve price, then the painting will sell at the seller's reserve price. Therefore, if the seller's reserve price is influenced by anchoring, so may be the selling price. As with buyers, past prices may influence the seller's perception of the true value of the painting. Past prices may influence the reserve price for a further reason if the seller exhibits loss aversion as in Kahneman and Tversky (1979). If the seller regards the previous price as a reference point with respect to which gains and losses are measured, then a high past price will lead to a high reserve price. The reserve price is of course set by negotiation with the auctioneer and the latter may be more interested in a quick sale than the seller, so this effect may be mitigated. ${ }^{4}$ The difficulty in measuring anchoring effects with regards to sellers is that the reserve price is secret and is therefore not observed. However, if sellers alter their secret reserve price because of anchoring or loss aversion, and bidders do not alter their bids, then one would expect these differences to affect the probability a painting sells.

\section{Auctioneers}

Anchoring effects in the auctioneer's presale estimates can occur for a variety of reasons. First, in publishing a presale estimate, the auctioneer may simply be trying to predict the price at which a painting sells in order to release more information to the market. Indeed, in conversations with experts at Christie's, an expert stated that the aim was that the actual sale price would be in the middle of the low and high estimate. Paul R. Milgrom and Richard J. Weber (1982) argue that a commitment to release all information available to buyers will be profitable for auctioneers when values are affiliated. If this is the case and if buyers use the anchoring heuristic, then the experts should do so as well. Secondly, as with buyers, the nominal value of the previous sale price may be influencing the experts' valuations. ${ }^{5}$ Finally, as the presale estimates are often set in negotiation with the sellers, and the convention is observed that the secret reserve price is at or below the low estimate, the seller's behavior may be influencing the auction experts. ${ }^{6}$

The possibility is present that the auctioneer's estimate, being an expert opinion, can influence both buyers and sellers and thus prices at auction, if this opinion is widely believed. In this case, auctioneers' experts could be using previous prices as an anchor when setting the presale estimate, and buyers and sellers could be using the presale estimate as an anchor. ${ }^{7}$

\footnotetext{
${ }^{4}$ See, for example, Greenleaf and Atanu Sinha (1996) for further discussion of the differing incentives of the auctioneer and seller with regard to the reserve price.

${ }_{5}^{5}$ As argued by Northcraft and Neale (1987).

${ }^{6}$ In real estate the buyer is normally willing to accept the listing price and so this may bound the maximum price that can be achieved. There may therefore be a trade-off between a lower asking price to achieve a quick sale and a higher one to boost the price (see, for example, Abdullah Yavas and Shiawee Yang 1995). In auctions the estimate is less important as a bound and so this strategic issue is perhaps less important.

${ }^{7}$ Christopher N. Avery and Judith A. Chevalier (1999) provide a description of the ways in which expert predictions can represent sentiment in the football betting market. Jiangping Mei and Michael Moses (2005) show that estimates for expensive paintings have a consistent upward bias and that some buyers are credulous.
} 
In summary, anchoring effects on the sale price (with no effect on the probability of sale) imply anchoring on the part of the bidders, either on the previous price or on the presale estimate. They are consistent with anchoring effects on reserve prices, because sellers are subject to anchoring or are simply responding to anchoring on the part of the buyers, but need not imply anything about sellers' behavior. Anchoring effects on the presale estimate imply that auctioneers are either anchoring on the previous price or are responding to anchoring on the part of the bidders. Anchoring effects on the probability of sale would imply that behavior on the part of the sellers and auctioneers is inconsistent with anchoring behavior on the part of the buyers. Below, we measure anchoring effects on sales prices, on auctioneer's presale estimates, and on the probability of sale.

\section{The Empirical Model}

Our empirical strategy is similar to that of Genesove and Mayer (2001). We construct a predicted price for each painting of the form

$$
\pi_{t}=\mathbf{X} \boldsymbol{\beta}+\delta_{t}
$$

$\mathbf{X}$ represents hedonic characteristics of the painting and $\delta_{t}$ is a time-specific effect.

We then estimate an equation of the following form:

$$
P R=\mu \pi+\lambda\left(P_{-1}-\pi\right)+\xi\left(P_{-1}-\pi_{-1}\right)
$$

$P R$ denotes either the sale price, the presale estimate, or an indicator variable equal to one if the painting sells, and zero otherwise; for convenience time subscripts have been dropped. We work in logs, which amounts to the assumption that the influence of past prices is felt in relative rather than absolute terms. Price is denoted by $P$, and the subscript -1 denotes value at the previous sale. Anchoring is captured in the expression $P_{-1}-\pi$, specifically by the extent that last period's price affects the dependent variable. The prediction is included in the expression $P_{-1}-\pi$, in order to clarify how anchoring is identified from other effects.

We need to consider possible biases in our estimation procedure. In particular, past price may influence the hedonic prediction because there may be components to quality that are not captured by the observable characteristics but that are observed either by the auctioneer, the buyers, or the sellers, or which the participants use past prices to learn about. The term $P_{-1}-\pi_{-1}$ captures these effects, using the identifying assumption that no new unobserved quality was introduced between the previous auction and the present auction. ${ }^{8}$ It is very unusual to have quality changes between auctions. Paintings are generally very well preserved, and in this dataset it is rare that paintings become known as fakes or that the attribution of the artist changes. Any information about the quality of the painting contained in $P_{-1}$ (past prices) but not reflected in $\pi_{-1}$ (past price predictions) will be contained in $P_{-1}-\pi_{-1}$. In the absence of anchoring effects, $P_{-1}$ should not appear separately in the regression. Since the demand for art, captured by the price index, varies over time, anchoring is identified: the terms $P_{-1}-\pi_{-1}$ and $P_{-1}-\pi$ are distinct.

Note that anchoring is measured in nominal terms, as is common in the literature. It is straightforward to adjust $P_{-1}$, or equivalently $\pi$, to allow for real effects such as inflation. With the current specification of the hedonic model, one cannot, however, allow for real effects relative to

\footnotetext{
${ }^{8}$ We show this formally in our working paper (2005).
} 
the general art index. This would be equivalent to replacing $\left(P_{-1}-\pi\right)$ by $\left(P_{-1}-\pi_{-1}\right)$ and so one could no longer separate reference point effects and unobserved quality.

\section{Data and Estimation}

\section{A. The Data}

In this paper, we use two datasets, a dataset on Impressionist and Modern Art auctions and a dataset on Contemporary Art auctions, as described in the Data Appendix. The Impressionist and Modern Art dataset contains 5,903 full observations (items with observable characteristics) on paintings auctioned in London, and 6,154 observations on paintings auctioned in New York between 1980 and 1990. The Contemporary Art dataset contains a total of 3,447 full observations on items auctioned at Christie's King Street in London between 1982 and 1994. We have restricted the original Contemporary Art dataset to artists who have appeared at least twice during the period. We use all of these observations to predict prices. Although these datasets are large in themselves, there are in actuality a relatively small number of sales that can be positively identified as repeat sales. ${ }^{9}$ This is a problem specific to working with sales of art. While there are some datasets, such as the dataset put together by Mei and Moses (2002), that deal with large numbers of repeat sales over huge expanses of time in varied locations, the large time intervals in their dataset between sales make it likely that the seller is not the same person who originally purchased the painting. Furthermore, anchoring is much more likely to be identified in a dataset such as ours where the average holding period is about 3 years, rather than in a dataset such as Mei and Moses's, where the average holding period is 28 years.

We make use of these datasets in two ways. First, we use observations in the datasets in which we have information on all hedonic characteristics in order to estimate the expected selling price. Due to currency differences (and not wishing to convert British pound sales into dollar sales because we are looking for reference points), we estimate separate hedonic equations for Impressionist Art in London, for Impressionist Art in New York, and for Contemporary Art. In our primary specifications we use only actual prices (information on sold items). However, as this truncates the dataset below the seller's reserve price and leads to biased estimates of actual prices - and may bias downward any anchoring effects - in another specification we use all items that were auctioned and proxy the selling price with 80 percent of the low estimate for items that went unsold at auction. ${ }^{10}$

Second, we use observations in which we have positively identified a first sale and a second listing in order to determine the extent to which presale low estimates are influenced by a reference point. In total, this consists of 47 paintings of Contemporary Art and 94 paintings of Impressionist and Modern Art. For the latter, we use only paintings that appeared in the same location (either New York or London) the second time as the location they were purchased in during their first appearance. This restriction is in order to mitigate substantial exchange rate effects on the reference point for the paintings. Summary statistics for these datasets are shown in detail in Tables 1 and 2 .

\footnotetext{
${ }^{9}$ By positively identify, we mean we have looked up the paintings and compared pictures in the presale catalogues to ensure the paintings are identical. Many paintings can have the same artist, title, and dimensions and yet be different paintings.

${ }^{10}$ William N. Goetzmann (1996) demonstrates the bias in sale prices. In the trade, secret reserve prices are generally considered to average about 80 percent of the low estimate. A bias in the measurement of anchoring effects could arise if the secret reserve price is not adjusted downward to the same extent as the buyer's valuation is adjusted downward after a painting has sold in a "cold" market. We cannot observe the anchoring effect for these paintings because these items go unsold.
} 
TABle 1-SAmple Means For IMPRESSIONiSt ArT

\begin{tabular}{|c|c|c|c|c|c|c|c|c|}
\hline & \multicolumn{2}{|c|}{ Sold items } & \multicolumn{2}{|c|}{ All items } & \multicolumn{2}{|c|}{ Repeat sales } & \multicolumn{2}{|c|}{ Repeat listings } \\
\hline & $\begin{array}{l}\text { London } \\
\text { (1) }\end{array}$ & $\begin{array}{c}\text { New York } \\
\text { (2) }\end{array}$ & $\begin{array}{l}\text { London } \\
\text { (3) }\end{array}$ & $\begin{array}{c}\text { New York } \\
\text { (4) }\end{array}$ & $\begin{array}{l}\text { London } \\
(5)\end{array}$ & $\begin{array}{c}\text { New York } \\
(6)\end{array}$ & $\begin{array}{l}\text { London } \\
(7)\end{array}$ & $\begin{array}{c}\text { New York } \\
(8)\end{array}$ \\
\hline Observations & 3,864 & 4,784 & 5,903 & 6,154 & 27 & 49 & 39 & 55 \\
\hline Low estimate & $\begin{array}{c}\$ 169,447 \\
(\$ 437,855)\end{array}$ & $\begin{array}{c}\$ 293,928 \\
(\$ 1,178,150)\end{array}$ & $\begin{array}{c}\$ 182,785 \\
(\$ 540,721)\end{array}$ & $\begin{array}{c}\$ 289,021 \\
(\$ 1,115,471)\end{array}$ & $\begin{array}{c}\$ 264,694 \\
(\$ 418,978)\end{array}$ & $\begin{array}{c}\$ 301,449 \\
(\$ 1,276,742)\end{array}$ & $\begin{array}{c}\$ 422,423 \\
(\$ 951,340)\end{array}$ & $\begin{array}{c}\$ 353,436 \\
(\$ 1,259,791)\end{array}$ \\
\hline High estimate & $\begin{array}{c}\$ 219,602 \\
(\$ 583,071)\end{array}$ & $\begin{array}{c}\$ 390,877 \\
(\$ 1,550,763)\end{array}$ & $\begin{array}{c}\$ 237,624 \\
(\$ 721,711)\end{array}$ & $\begin{array}{c}\$ 384,270 \\
(\$ 1,480,446)\end{array}$ & $\begin{array}{c}\$ 333,081 \\
(\$ 534,420)\end{array}$ & $\begin{array}{c}\$ 400,653 \\
(\$ 1,702,771)\end{array}$ & $\begin{array}{c}\$ 525,333 \\
(\$ 1,165,601)\end{array}$ & $\begin{array}{c}\$ 459,400 \\
(\$ 1,667,088)\end{array}$ \\
\hline Sale price & $\begin{array}{c}\$ 221,801 \\
(\$ 712,396)\end{array}$ & $\begin{array}{c}\$ 383,649 \\
(\$ 1,713,584)\end{array}$ & $\begin{array}{l}\$ 202,682^{\mathrm{a}} \\
(\$ 662,923)\end{array}$ & $\begin{array}{c}\$ 346,662^{\mathrm{a}} \\
(\$ 1,546,959)\end{array}$ & $\begin{array}{c}\$ 352,129 \\
(\$ 677,911)\end{array}$ & $\begin{array}{c}\$ 351,341 \\
(\$ 1,284,566)\end{array}$ & $\begin{array}{l}\$ 435,120^{\mathrm{a}} \\
(\$ 892,153)\end{array}$ & $\begin{array}{c}\$ 380,911^{\mathrm{a}} \\
(\$ 1,244,206)\end{array}$ \\
\hline $\begin{array}{l}\text { Months since } \\
\text { last sale }\end{array}$ & & & & & $\begin{array}{c}46 \\
(28)\end{array}$ & $\begin{array}{c}34 \\
(19)\end{array}$ & $\begin{array}{c}45 \\
(24)\end{array}$ & $\begin{array}{c}35 \\
(20)\end{array}$ \\
\hline
\end{tabular}

Note: Standard deviations are in parentheses.

${ }^{\text {a }}$ The sale price for unsold items in columns 3 and 4 and columns 7 and 8 is proxied by 80 percent of the low estimate.

Table 2-Sample Means for Contemporary Art

\begin{tabular}{lcccc}
\hline \hline Variables & $\begin{array}{c}\text { Sold items } \\
(1)\end{array}$ & $\begin{array}{c}\text { All items } \\
(2)\end{array}$ & $\begin{array}{c}\text { Repeat sales } \\
(3)\end{array}$ & $\begin{array}{c}\text { Repeat listings } \\
(4)\end{array}$ \\
\hline Observations & 2,666 & 3,447 & 34 & 47 \\
Low estimate & $\$ 19,336$ & $\$ 21,836$ & $\$ 20,674$ & $\$ 20,724$ \\
& $(\$ 38,935)$ & $(\$ 60,052)$ & $(\$ 19,883)$ & $(\$ 20,928)$ \\
High estimate & $\$ 25,948$ & $\$ 29,173$ & $\$ 28,050$ & $\$ 27,886$ \\
& $(\$ 52,747)$ & $(\$ 82,669)$ & $(\$ 28,081)$ & $(\$ 28,843)$ \\
Sale price & $\$ 24,769$ & $\$ 24,662^{\mathrm{a}}$ & $\$ 23,141$ & $\$ 21,356^{\mathrm{a}}$ \\
& $(\$ 48,964)$ & $(\$ 58,293)$ & $(\$ 20,724)$ & $(\$ 20,382)$ \\
Months since & & 35 & 37 & \\
Last sale & & $(21)$ & $(22)$ & \\
\hline
\end{tabular}

Note: Standard deviations are in parentheses.

${ }^{\text {a }}$ The sale price for unsold items in columns 2 and 4 is proxied by 80 percent of the low estimate.

\section{B. Hedonic Predictions}

For the hedonic predictions of price, the log of the sale price is regressed on the hedonic painting characteristics in addition to half-year time dummies for each period. The hedonic characteristics used for Impressionist Art are: painting date, length, width, signed, monogrammed, stamped, medium in which it was painted, and artist. The following hedonic characteristics are used for Contemporary Art: painting date, length, width, medium, and artist. For Impressionist Art, we estimate separate equations for paintings sold in London and paintings sold in New York. In Table 3 below we report the results of the hedonic regressions; prices and all characteristics are in logs. There are two things to note about the hedonic regressions. First, we are explaining a lot of the variation in price with the hedonic regressions (the $R^{2}$ for London and New York is 0.75 and 0.79 , respectively, for Impressionist Art and 0.83 for Contemporary Art). If only time and artist dummies are included in the regressions, the $R$-squareds drop to 0.36 and 0.60 , respectively, and if only time dummies are included, the $R$-squareds drop to 0.18 and 0.28 (these regressions are not reported). Secondly, our observable characteristics are highly significant. Size, painting data, and signature really do make a difference to the price of a painting! ${ }^{11}$

\footnotetext{
${ }^{11}$ Hedonic regressions have been used extensively in estimating indices for art. See Orley Ashenfelter and Graddy $(2003,2006)$ for a summary.
} 
Table 3-Hedonic Regression Dependent Variable: Price

\begin{tabular}{|c|c|c|c|c|c|c|}
\hline & \multicolumn{4}{|c|}{ Impressionist Art } & \multicolumn{2}{|c|}{ Contemporary Art } \\
\hline & \multicolumn{2}{|c|}{ Sold sample } & \multicolumn{2}{|c|}{ Full sample ${ }^{\mathrm{a}}$} & \multirow[b]{2}{*}{$\begin{array}{l}\text { Sold sample } \\
\text { (5) }\end{array}$} & \multirow[b]{2}{*}{$\begin{array}{l}\text { Full sample } \\
\qquad(6)\end{array}$} \\
\hline & $\begin{array}{l}\text { London } \\
\text { (1) }\end{array}$ & $\begin{array}{c}\text { New York } \\
\text { (2) }\end{array}$ & $\begin{array}{l}\text { London } \\
\text { (3) }\end{array}$ & $\begin{array}{c}\text { New York } \\
\text { (4) }\end{array}$ & & \\
\hline Date painted & $\begin{array}{l}-0.588 \\
(0.081)\end{array}$ & $\begin{array}{l}-0.864 \\
(0.075)\end{array}$ & $\begin{array}{l}-0.477 \\
(0.061)\end{array}$ & $\begin{array}{l}-0.906 \\
(0.067)\end{array}$ & $\begin{array}{l}-0.557 \\
(0.063)\end{array}$ & $\begin{array}{l}-0.541 \\
(0.057)\end{array}$ \\
\hline Length & $\begin{array}{c}0.691 \\
(0.046)\end{array}$ & $\begin{array}{c}0.865 \\
(0.042)\end{array}$ & $\begin{array}{c}0.623 \\
(0.036)\end{array}$ & $\begin{array}{c}0.808 \\
(0.036)\end{array}$ & $\begin{array}{c}0.509 \\
(0.040)\end{array}$ & $\begin{array}{c}0.523 \\
(0.035)\end{array}$ \\
\hline Width & $\begin{array}{c}0.527 \\
(0.045)\end{array}$ & $\begin{array}{c}0.403 \\
(0.041)\end{array}$ & $\begin{array}{c}0.551 \\
(0.036)\end{array}$ & $\begin{array}{c}0.419 \\
(0.035)\end{array}$ & $\begin{array}{c}0.535 \\
(0.040)\end{array}$ & $\begin{array}{c}0.528 \\
(0.034)\end{array}$ \\
\hline Signed & $\begin{array}{c}0.388 \\
(0.055)\end{array}$ & $\begin{array}{c}0.502 \\
(0.050)\end{array}$ & $\begin{array}{c}0.377 \\
(0.042)\end{array}$ & $\begin{array}{c}0.463 \\
(0.042)\end{array}$ & & \\
\hline Monagrammed & $\begin{array}{c}0.116 \\
(0.040)\end{array}$ & $\begin{array}{c}0.101 \\
(0.035)\end{array}$ & $\begin{array}{c}0.104 \\
(0.032)\end{array}$ & $\begin{array}{c}0.086 \\
(0.031)\end{array}$ & & \\
\hline Stamped & $\begin{array}{c}0.056 \\
(0.024)\end{array}$ & $\begin{array}{c}0.008 \\
(0.021)\end{array}$ & $\begin{array}{c}0.047 \\
(0.019)\end{array}$ & $\begin{array}{c}0.006 \\
(0.018)\end{array}$ & & \\
\hline Medium dummies & 12 & 12 & 12 & 12 & 19 & 19 \\
\hline Artist dummies & 55 & 54 & 56 & 55 & 282 & 302 \\
\hline Time dummies & 21 & 20 & 21 & 20 & 24 & 24 \\
\hline Constant & yes & yes & yes & yes & yes & yes \\
\hline Observations & 3,864 & 4,784 & 5,903 & 6,154 & 2,666 & 3,447 \\
\hline$R^{2}$ & 0.75 & 0.79 & 0.74 & 0.78 & 0.83 & 0.83 \\
\hline
\end{tabular}

Note: Standard errors are in parentheses.

${ }^{\text {a }}$ Prices for unsold items in the full sample regressions are proxied by 80 percent of the low estimate.

In Figures 1 and 2, we plot the price indices for the two datasets using all prices, where the price for items that were unsold is replaced by 80 percent of the low estimate. ${ }^{12}$ This is constructed as the exponential of the coefficients on the half-year date dummy variables. The price indices are important, as it is the change in the price index, coupled with the assumption that the unobservable quality of a painting remains the same between sales, that allows us to identify anchoring effects. There are a few things to note about Figure 1. First, there is a very large rise in price from about 1985 to 1989, and then a drop-off at the end. In Tables 4 and 5, we are primarily relying on the times when there is a general market gain or loss to estimate the anchoring effects. In the Impressionist dataset, there are 84 gains, but only 13 losses. Further, as we have included a half-year rather than a full-year index, the index appears more volatile than indices in which a full year is included. This is because the coefficients on time are capturing some unobserved quality effects between auctions.

Figure 2 plots the index for Contemporary Art. For Contemporary Art, very often the halfyear time dummies encompass only one sale. For example, there is a huge spike coincident with the sale on November 30, 1989. The average price for this half year was approximately twice the average price for the preceding half-year period. This was immediately before the crash in 1990 . Again, because some sales are more "important" than other sales, the time dummies are also picking up unobserved quality effects. In the Contemporary Art dataset, there are 27 gains and 20 losses.

\footnotetext{
${ }^{12}$ The shape of the plot of the index using only sold prices looks very similar-we plotted this sample to counteract some of the known bias in sold prices.
} 


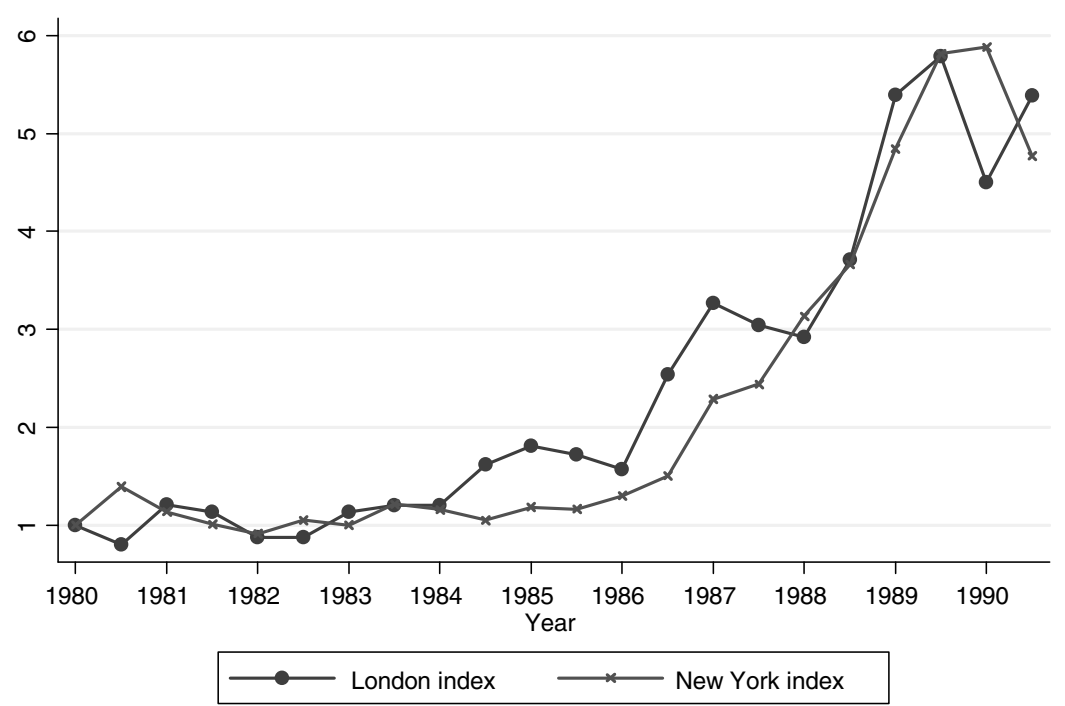

Figure 1. IMPRESSIONIST ART, 1980-1990

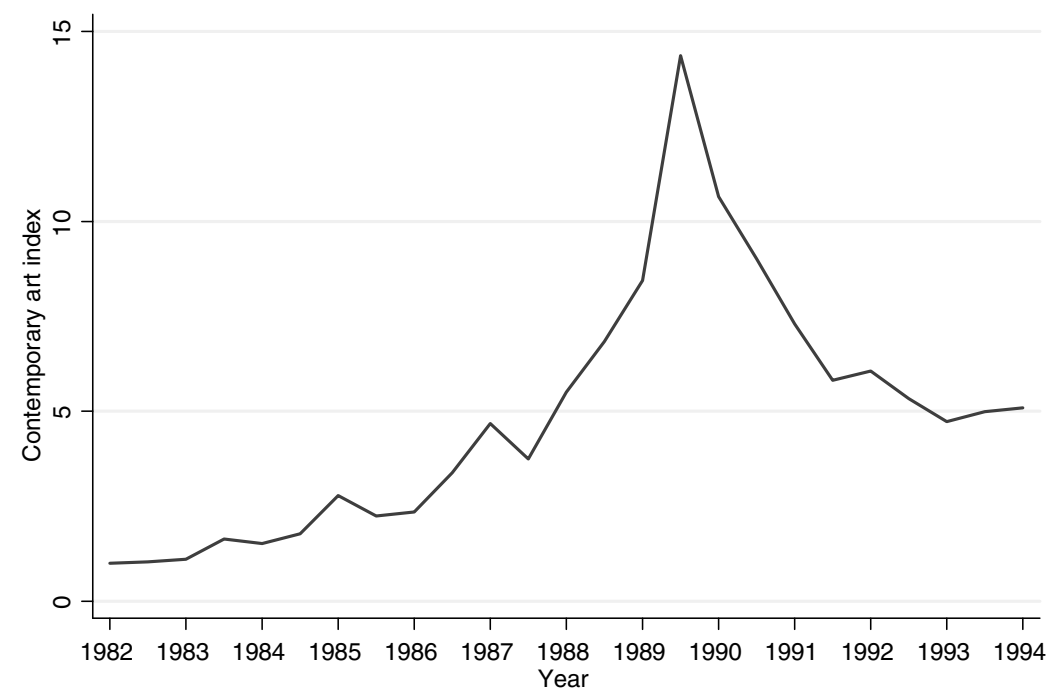

Figure 2. CONTEMPorary ART, 1992-1994

To construct the hedonic predictions and the indices, we used hammer prices, and not prices including buyers' commissions, as we believe buyers, sellers, and auctioneers focus on hammer prices fetched at auction. We relax this assumption in Section IVD.

\section{Anchoring Effects}

Tables 4 and 5 report OLS regression results for the regression equation outlined in equation (1) above. In addition to the variables described in equation (1), we control for the months since the previous sale in the regression. We use levels, rather than logs, for this variable, as the fit is better. 
Table 4-Anchoring EfFects: Impressionist ArT

\begin{tabular}{|c|c|c|c|c|c|c|}
\hline & \multicolumn{3}{|c|}{ Dependent variable: Price } & \multicolumn{3}{|c|}{ Dependent variable: Low estimate } \\
\hline & \multicolumn{2}{|c|}{ Sold sample } & \multirow{2}{*}{$\begin{array}{c}\text { Full sample }^{\mathrm{a}} \\
\begin{array}{c}\text { All } \\
(3)\end{array}\end{array}$} & \multicolumn{2}{|c|}{ Sold sample } & \multirow{2}{*}{$\begin{array}{c}\text { Full sample } \\
\text { All } \\
(6)\end{array}$} \\
\hline & $\begin{array}{l}\text { All } \\
(1)\end{array}$ & $<\underset{(2)}{42 \text { months }}$ & & $\begin{array}{l}\text { All } \\
(4)\end{array}$ & $<\underset{(5)}{42 \text { months }}$ & \\
\hline Anchoring effect & $\begin{array}{c}0.708 \\
(0.131)\end{array}$ & $\begin{array}{c}0.852 \\
(0.139)\end{array}$ & $\begin{array}{c}0.625 \\
(0.131)\end{array}$ & $\begin{array}{c}0.679 \\
(0.102)\end{array}$ & $\begin{array}{c}0.805 \\
(0.100)\end{array}$ & $\begin{array}{c}0.698 \\
(0.103)\end{array}$ \\
\hline $\begin{array}{l}\text { Predicted price } \\
\text { at current auction }\end{array}$ & $\begin{array}{c}0.949 \\
(0.041)\end{array}$ & $\begin{array}{c}0.946 \\
(0.046)\end{array}$ & $\begin{array}{c}0.982 \\
(0.036)\end{array}$ & $\begin{array}{c}0.923 \\
(0.038)\end{array}$ & $\begin{array}{c}0.959 \\
(0.040)\end{array}$ & $\begin{array}{c}0.976 \\
(0.037)\end{array}$ \\
\hline $\begin{array}{l}\text { Residual from last } \\
\text { sale price }\end{array}$ & $\begin{array}{c}0.256 \\
(0.142)\end{array}$ & $\begin{array}{c}0.087 \\
(0.151)\end{array}$ & $\begin{array}{c}0.323 \\
(0.141)\end{array}$ & $\begin{array}{c}0.279 \\
(0.099)\end{array}$ & $\begin{array}{c}0.141 \\
(0.089)\end{array}$ & $\begin{array}{c}0.259 \\
(0.103)\end{array}$ \\
\hline $\begin{array}{l}\text { Months since } \\
\text { last sale }\end{array}$ & $\begin{array}{c}0.012 \\
(0.003)\end{array}$ & $\begin{array}{c}0.016 \\
(0.006)\end{array}$ & $\begin{array}{c}0.011 \\
(0.003)\end{array}$ & $\begin{array}{c}0.010 \\
(0.004)\end{array}$ & $\begin{array}{c}0.017 \\
(0.006)\end{array}$ & $\begin{array}{c}0.011 \\
(0.004)\end{array}$ \\
\hline Constant & $\begin{array}{c}0.683 \\
(0.476)\end{array}$ & $\begin{array}{c}0.674 \\
(0.535)\end{array}$ & $\begin{array}{c}0.246 \\
(0.436)\end{array}$ & $\begin{array}{c}0.822 \\
(0.431)\end{array}$ & $\begin{array}{c}0.280 \\
(0.428)\end{array}$ & $\begin{array}{c}0.238 \\
(0.428)\end{array}$ \\
\hline$R^{2}$ & 0.89 & 0.90 & 0.90 & 0.91 & 0.94 & 0.90 \\
\hline Observations & 76 & 54 & 94 & 76 & 54 & 94 \\
\hline
\end{tabular}

Note: Standard errors are calculated using Stata's robust estimation method.

${ }^{\text {a }}$ Prices for unsold items are proxied by 80 percent of the low estimate.

TABle 5-AnChoring EfFects: CONTEMPorary ArT

\begin{tabular}{|c|c|c|c|c|c|c|}
\hline & \multicolumn{3}{|c|}{ Dependent variable: Price } & \multicolumn{3}{|c|}{ Dependent variable: Low estimate } \\
\hline & \multicolumn{2}{|c|}{ Sold sample } & \multirow{2}{*}{$\begin{array}{c}\text { Full sample }{ }^{\mathrm{a}} \\
\text { All } \\
(3)\end{array}$} & \multicolumn{2}{|c|}{ Sold sample } & \multirow{2}{*}{$\begin{array}{c}\text { Full sample }^{\mathrm{a}} \\
\text { All } \\
(6)\end{array}$} \\
\hline & $\begin{array}{l}\text { All } \\
(1)\end{array}$ & $<\underset{(2)}{42 \text { months }}$ & & $\begin{array}{l}\text { All } \\
(4)\end{array}$ & $<\underset{(5)}{42 \text { months }}$ & \\
\hline Anchoring effect & $\begin{array}{c}0.121 \\
(0.118)\end{array}$ & $\begin{array}{c}0.498 \\
(0.192)\end{array}$ & $\begin{array}{c}0.183 \\
(0.091)\end{array}$ & $\begin{array}{c}0.294 \\
(0.132)\end{array}$ & $\begin{array}{c}0.729 \\
(0.189)\end{array}$ & $\begin{array}{c}0.300 \\
(0.099)\end{array}$ \\
\hline $\begin{array}{l}\text { Predicted price } \\
\text { at current auction }\end{array}$ & $\begin{array}{c}0.993 \\
(0.059)\end{array}$ & $\begin{array}{c}1.037 \\
(0.048)\end{array}$ & $\begin{array}{l}1.015 \\
(0.047)\end{array}$ & $\begin{array}{c}0.991 \\
(0.058)\end{array}$ & $\begin{array}{l}1.067 \\
(0.057)\end{array}$ & $\begin{array}{c}0.977 \\
(0.040)\end{array}$ \\
\hline $\begin{array}{l}\text { Residual from last } \\
\text { sale price }\end{array}$ & $\begin{array}{c}0.333 \\
(0.208)\end{array}$ & $\begin{array}{c}-0.135 \\
(0.255)\end{array}$ & $\begin{array}{c}0.379 \\
(0.146)\end{array}$ & $\begin{array}{c}0.215 \\
(0.218)\end{array}$ & $\begin{array}{c}-0.214 \\
(0.337)\end{array}$ & $\begin{array}{c}0.324 \\
(0.154)\end{array}$ \\
\hline $\begin{array}{l}\text { Months since } \\
\text { last sale }\end{array}$ & $\begin{array}{c}0.001 \\
(0.004)\end{array}$ & $\begin{array}{l}-0.020 \\
(0.006)\end{array}$ & $\begin{array}{c}0.002 \\
(0.004)\end{array}$ & $\begin{array}{c}0.005 \\
(0.005)\end{array}$ & $\begin{array}{c}-0.023 \\
(0.008)\end{array}$ & $\begin{array}{c}0.006 \\
(0.004)\end{array}$ \\
\hline Constant & $\begin{array}{c}0.028 \\
(0.531)\end{array}$ & $\begin{array}{c}-0.012 \\
(0.486)\end{array}$ & $\begin{array}{c}-0.292 \\
(0.408)\end{array}$ & $\begin{array}{r}-0.246 \\
(0.538)\end{array}$ & $\begin{array}{c}-0.395 \\
(0.520)\end{array}$ & $\begin{array}{c}-0.148 \\
(0.357)\end{array}$ \\
\hline$R^{2}$ & 0.90 & 0.95 & 0.91 & 0.90 & 0.95 & 0.92 \\
\hline Observations & 34 & 22 & 47 & 34 & 22 & 47 \\
\hline
\end{tabular}

Note: Standard errors are calculated using Stata's robust estimation method.

${ }^{\text {a }}$ Prices for unsold items are proxied by 80 percent of the low estimate.

We use different samples in the different columns. In columns 1 and 4 we use only sold items in the regressions; the dependent variable in column 1 is the actual price fetched at auction-the hammer price. In columns 2 and 5, we restrict the sample to sold items that were reauctioned within $3 \frac{1}{2}$ years of the first sale. In these equations we are testing whether anchoring effects are stronger for items brought back more quickly after the first sale. We chose $3 \frac{1}{2}$ years as a cutoff point to allow enough observations for the regressions (which is especially important in the Contemporary Art dataset), while at the same time allowing a shorter period of time between 
sales; the results are very robust for both samples to the choice of cutoff point around 42 months. Again, in column 2 of both tables, the dependent variable is the hammer price. In columns 3 and 6 , we use information on all items put up for auction, and we proxy the sale price for unsold items by 80 percent of the low estimate.

The results for Impressionist Art indicate there are strong anchoring effects. The interpretation of the coefficient is that a 10 percent positive difference between the previous sale price and the hedonic prediction would lead the final price to be adjusted upward toward the previous price (the anchor) by between 6.2 percent and 8.5 percent of this difference, depending on the specification, with symmetric results for negative differences. ${ }^{13}$ The results for the presale low estimate are very similar to the regressions that use price as the dependent variable. The results are very similar whether all items are used, with price replaced by 80 percent of the low estimate, or whether only sold items are used. Finally, the results indicate that anchoring effects are stronger for items that are reauctioned more quickly after the first sale.

Anchoring effects do not appear to have been as large in the Contemporary Art dataset, though for items that are sold within $3 \frac{1}{2} 2$ years, a 10 percent positive difference between the previous price and the hedonic prediction would lead the final price to be adjusted upward toward the previous price (the anchor) by about 5 percent of this difference, with symmetric results for negative differences. Anchoring effects are very much stronger for those items that have returned to auction within $3 \frac{1}{2}$ years of the first sale. The lack of significance in column 1 could be attributed to truncation bias in that only sold items are used. Indeed, in column 3 , we get marginal significance at the 5 percent level if prices for unsold items are proxied by 80 percent of the low estimate. Another explanation could be that the meteoric rise and fall in contemporary art prices during the sample makes past prices less obvious as an anchor, though when only items that were sold within a shorter period of time are used as in column 2, anchoring effects are very strong.

Overall, the anchoring effects for the presale estimates for Contemporary Art appear to be slightly stronger than the anchoring effects on prices. A 10 percent positive difference between the previous price and the hedonic prediction would lead the final price to be adjusted upward toward the previous price (the anchor) by between about 3 and 7 percent of this difference depending on the specification, with symmetric results for negative differences. The anchoring effects are statistically significant in all samples in which the presale low estimate is the dependent variable.

The coefficient on predicted value is not significantly different from one in any of the regressions, except marginally in column 4 of Table 4 . The regressions also indicate that the hedonic model, as expected, does not pick up all fixed effects. The coefficients on lagged residual are significant in some specifications, though not in the specification when only items are used that have been brought back to auction within $3 \frac{1}{2}$ years.

\section{Robustness checks}

To check for robustness, we have separated out the fixed effects from the time effects in the prediction variable, but find that the coefficients on each are not significantly different from one another. We also tried different specifications for the prediction equation, using only time effects and artist dummy variables, or using only time effects. These different specifications made no difference to the estimated coefficients for Impressionist Art. When artist and time dummies are

\footnotetext{
${ }^{13}$ We allow for asymmetric results in our working paper, Beggs and Graddy (2005), but find that coefficients on losses and gains are not significantly different from each other. That is, we find no evidence of loss aversion. As noted by Genesove and Mayer (2001) ordinary least squares is in general inconsistent when there is loss aversion, but we introduce a consistent nonlinear estimator.
} 
both used for the prediction equation in the Contemporary Art sample, the estimated coefficients are also virtually identical to when all observable variables are used. These checks appear to indicate that the exact choice of observables in our prediction equations is not influencing our results. The point estimate for the anchoring effect increases slightly in the Contemporary Art sample only when time dummies alone are used for the prediction equation, but is still within one standard deviation of our estimates in Table 5. We are now using a poor predictor, and so past price is more informative about unobserved quality, but our estimation controls for this. The coefficient of the lagged residual becomes larger, as one would expect, but the point estimates of the anchoring effects are not significantly changed. Hence, our results seem robust to choice of the prediction equation.

As discussed above, the anchoring effects for the regression estimates are based on the hammer prices. The regression estimates with the buyers' commissions added in are very close to being identical to the regression estimates without buyers' commissions. Buyers' commissions were 10 percent on all paintings in both datasets before 1993. Buyers' commissions on paintings in the Contemporary Art dataset that were sold in 1993 or later were 15 percent on the first $\$ 30,000$ and 10 percent on amounts greater than $\$ 30,000$. We have little information on sellers' commissions. During the period in question, Christie's and Sotheby's would vary the sellers' commissions or waive the sellers' commissions completely as they were competing with one another for paintings. Our data come largely from the period before any price fixing on commissions took place at the auction houses.

An interesting check would be to test whether individuals were anchoring on real prices or nominal prices by deflating prices by the art index (using CPI as a deflator had no effect, as changes in art prices swamp changes in CPI). However, as noted above, it is precisely changes in the art index that identify the reference point effect from the error correction term. ${ }^{14}$

In our presale estimate regressions, we used the low presale estimate as the regressor because of its relationship to the secret reserve price. As another check, however, we looked at the effect of reference points on the high estimates. Again, the results are very similar to our results when using low estimates.

\section{E. The Probability of Sale}

We also estimated a probit model to predict whether an item is sold based on the entire range of independent variables in Tables 4 and 5: using the Wald test, we could not reject that the coefficients on all the variables were simultaneously zero. ${ }^{15}$ We interpret this result to imply that reference points have no effect on the probability of sale. Thus, while the auctioneers' and sellers' behavior may exhibit reference point effects in choosing the low estimate and secret reserve, it does so in a way consistent with buyers' behaviour.

\section{Interpretation}

In this paper, we have found strong support for anchoring effects. We interpret these effects as anchoring on the part of the buyers, with the sellers and auctioneers either anticipating anchoring

\footnotetext{
${ }^{14}$ A referee suggested that we rerun the hedonic regressions, allowing for taste changes over time. We were able to do this for the Impressionist Art sample by interacting artist fixed effects with yearly fixed effects (using year dummies rather than half-year dummies). We then adjusted last period's price by the price index as estimated from the hedonic regressions and reran the regressions in Table 4. We did not find any significant anchoring effects in any of the regressions, cautiously suggesting that individuals anchor on nominal prices rather than real prices.

${ }^{15}$ For Impressionist Art, the chi-squared (5) is 6.91 resulting in a $p$-value of 0.2275 , and for Contemporary Art, the chi-squared (5) is 6.43, resulting in a $p$-value of 0.2670 .
} 
on the part of the buyers or exhibiting similar anchoring effects themselves. In our working paper (Beggs and Graddy 2005), we found no evidence of asymmetric effects between gains and losses. Buyers are unlikely to exhibit loss aversion, as they do not possess the painting. Botond Köszegi and Matthew Rabin (2006) argue that sellers in markets, as opposed to laboratories, may also not exhibit loss aversion if they are expecting to trade and so do not regard owning the objects as their reference point. Furthermore, in an auction environment, loss aversion would as likely show up in items not being brought to market as in prices, which again we find some evidence for in Beggs and Graddy (2005).

Reference dependence and anchoring are often used interchangeably. Kahneman (1992), however, defines reference dependence as something that influences the reference point in the measurement of gains and losses when they are valued asymmetrically, anchoring as something that influences judgement of what is normal more generally. Our evidence supports Kahneman's definition of anchoring but does not support Kahneman's definition of reference dependence.

As noted in the introduction, anchoring often results in bias. In this study, however, we do not find that the presale estimates are biased relative to the final prices. The bias for both final prices and presale estimates is shown relative to a statistical prediction of the price that should occur, given current market conditions and observable characteristics of the painting. We interpret this finding as anchoring.

\section{DATA APPENDiX}

The first dataset, on Impressionist and Modern Art auctions, was constructed by Orley Ashenfelter and Andrew Richardson. This dataset is restricted to 58 selected Impressionist and Modern artists and includes only paintings, not sculpture. These artists were chosen primarily because their work is well represented at auction. The period covered is 1980 to 1990, and the dataset includes over 16,000 items in 150 auctions that were held in London and New York at both Christie's and Sotheby's. The auction prices were collected from public price lists, and the estimated prices and observable painting characteristics were collected from the presale catalogues. This dataset does not include all items sold in each auction, only a sample of the 58 selected artists. Furthermore, we have prices only for items that were sold at auction. This dataset has been used in Richardson (1992), John M. Abowd and Ashenfelter (1989), Beggs and Graddy (1997), and Ashenfelter and Graddy (2003). For the dataset used in this paper, we took only those observations for which we have information on all observable characteristics, leaving us with a total of 12,057 observations.

The second dataset is a dataset on Contemporary Art that was constructed by Kathryn Graddy and includes all sales of Contemporary Art at Christie's auction house on King Street in London between 1982 and 1994. The data were gathered from the Christie's archives, and for each item the observable characteristics were hand-copied from the presale catalogues. The information on whether or not a lot is sold and the final bid from 1988 onward was taken primarily from Christie's internal property system. Before 1988, many of the lots were missing from the internal system. It appeared that, after a certain period of time, some of the lots were deleted from the system, for no predictable reason. From December 1982 through December 1987, access to the auctioneer's books was obtained and used to track the missing items. The Contemporary Art dataset includes 35 auctions and approximately 4,500 items for sale. This dataset has been used in Beggs and Graddy (1997), and Ashenfelter and Graddy (2003). For this paper, we restricted the dataset in two ways. First, we use only items for which we have information on all observable characteristics, and we use only items created by artists for which we have at least two observations. 


\section{REFERENCES}

Abowd, John M., and Orley Ashenfelter. 1989. "Art Auctions: Prices Indices and Sale Rates for Impressionist and Contemporary Pictures." Unpublished.

-Ashenfelter, Orley, and Kathryn Graddy. 2003. "Auctions and the Price of Art." Journal of Economic Literature, 41(3): 763-87.

Ashenfelter, Orley, and Kathryn Graddy. 2006. "Art Auctions.” In Handbook on the Economics of Art and Culture, ed. Victor Ginsburgh and David Throsby, 909-45. Amsterdam: Elsevier Science.

-Avery, Christopher N., and Judith Chevalier. 1999. "Identifying Investor Sentiment from Price Paths: The Case of Football Betting." Journal of Business, 72(4): 493-521.

Barberis, Nicholas, Ming Huang, and Tano Santos. 2001. "Prospect Theory and Asset Prices." Quarterly Journal of Economics, 116(1): 1-53.

-Beggs, Alan, and Kathryn Graddy. 1997. "Declining Values and the Afternoon Effect: Evidence from Art Auctions." RAND Journal of Economics, 28(3): 544-65.

Beggs, Alan, and Kathryn Graddy. 2005. "Testing for Reference Dependence: An Application to the Art Market.” CEPR Discussion Paper 4982.

Chapman, Gretchen B., and Eric J. Johnson. 2002. "Incorporating the Irrelevant: Anchors in Judgments of Belief and Value." In Heuristics and Biases: The Psychology of Intuitive Judgment, ed. Thomas Gilovich, Dale Griffin, and Daniel Kahneman, 120-38. Cambridge: Cambridge University Press.

Genesove, David, and Christopher Mayer. 2001. "Loss Aversion and Seller Behavior: Evidence from the Housing Market.” Quarterly Journal of Economics, 116(4): 1233-60.

Goetzmann, William N. 1996. "How Costly Is the Fall from Fashion? Survivorship Bias in the Painting Market." In Economics of the Arts: Selected Essays, ed. Victor A. Ginsburgh and Pierre-Michel Menger, 71-84. Amsterdam: Elsevier Science, North-Holland.

-Greenleaf, Eric A. 1995. "The Impact of Reference Price Effects on the Profitability of Price Promotions." Marketing Science, 14(1): 82-104.

Greenleaf, Eric A., and Atanu Sinha. 1996. "Combining Buy-in Penalties with Commissions at Art Houses." Management Science, 42(4): 529-40.

Kahneman, Daniel. 1992. "Reference Points, Anchors, Norms and Mixed Feelings." Organizational Behavior and Human Decision Processes, 51(2): 296-312.

-Kahneman, Daniel, and Amos Tversky. 1979. "Prospect Theory: An Analysis of Decision under Risk." Econometrica, 47(2): 263-91.

Kőszegi, Botond, and Matthew Rabin. 2006. "A Model of Reference-Dependent Preferences." Quarterly Journal of Economics, 121(4): 1133-65.

-Mei, Jianping, and Michael Moses. 2002. "Art as an Investment and the Underperformance of Masterpieces." American Economic Review, 92(5): 1656-68.

-Mei, Jianping, and Michael Moses. 2005. "Vested Interest and Biased Price Estimates: Evidence from an Auction Market.” Journal of Finance, 60(5): 2409-35.

-Milgrom, Paul R., and Robert J. Weber. 1982. "A Theory of Auctions and Competitive Bidding." Econometrica, 50(5): 1089-1122.

Northcraft, Gregory B., and Margaret A. Neale. 1987. "Experts, Amateurs and Real Estate: An Anchoring-and-Adjustment Perspective on Property Pricing Decisions." Organizational Behavior and Human Decision Processes, 39(1): 84-97.

- Rajendran, K. N. (Raj), and Gerard J. Tellis. 1994. "Contextual and Temporal Components of Reference Price." Journal of Marketing, 58(1): 22-34.

Richardson, Andrew. 1992. "An Econometric Analysis of the Auction Market for Impressionist and Modern Pictures, 1980-1991." Senior thesis, Princeton University.

-Taylor, William M. 1983. “The Estimation of Quality-Adjusted Rates of Return in Stamp Auctions.” Journal of Finance, 38(4): 1095-1110.

Tversky, Amos, and Daniel Kahneman. 1982. "Judgements of and by Representativeness." In Judgement under Uncertainty: Heuristics and Biases, ed. Daniel Kahneman, Paul Slovic, and Amos Tversky, 84-98. Cambridge: Cambridge University Press.

- Yavas, Abdullah, and Shiawee Yang. 1995. "The Strategic Role of Listing Price in Marketing Real Estate: Theory and Evidence." Real Estate Economics, 23(3): 347-68. 